\title{
THE LOCAL KING'S COURT IN THE REIGN OF WILLIAM I
}

Of the incidents of the reign of William the Conqueror which indicate the attitude of the new government towards Saxon institutions, certain lawsuits held in various counties have long been considered of especial importance, ${ }^{x}$ and they are certainly deserving of re-examination in the light of our present knowledge. As my purpose in doing this is to ascertain if these cases give any information on the relation of Saxon and Norman institutions to one another during the reign of the Conqueror, I shall disregard or pass lightly over other matters. I shall not follow a chronological order, but begin with a case from the second half of the reign, because our accounts of it are the most detailed and .ndicate most completely the points of interest in all the cases.

Probably soon after 1079 Wulfstan, Bishop of Worcester, brought suit against Walter, Abbot of Evesham, ${ }^{2}$ for servitia et consuetudines withheld. ${ }^{2}$ Bearing directly on this suit we have

\footnotetext{
1 See the references from individual cases below.

2 Freeman, Norman Conquest, V. 509-510 (Am. Ed.) ; Round. Domesday Studies, II. 542-545; Irictoria County History, Worcestershire, $254 \mathrm{ff}$.

3 Consuetudines, though a general word, is probably to be taken in a connection like this to mean the right to receive payments which may be of various kinds. Servitia et consuetudines is proper feudal language. So are other expressions of these documents. Both the King and Geoffrey in Nos. 2 and 3 speak of the abbot's owing service to the bishop sicut alii sui feudati.. Still more feudal in character is the King's claim to a share in the services due the bishop. In No. 2 some, at least, of the services which the bishop has recovered are mea servitia ad suum huindredum; in No. 1, those who hold the bishop's lands should always be ready in meo servitio ct suo. I hardly think, however, that servitia et consuetudines can be taken here as evidence of feudalization, and perhaps none of the expressions can be, though of cumulative force with other evidence for which see below. The servitia et consuptudines for which the bishop is suing plainly go back into Saxon times and, though some of them, the expeditiones, for instance, may have been feudally made over, there is nothing in these documents which makes it necessary to suppose that they had been. Nor is it necessary to suppose that feudalization took place everywhere, in all bishoprics for example, at the same date. It is likely that it was carried through comparatively early in the reign. That the language of these documents is consistent with feudal relationships should at any rate not be overlooked. Mr. Round has shown conclusively, I think, that both the-bishopric and the abbey lands had been subinfeudated
} 
five separate documents which are in the probable order of date: 1. The original writ by which the suit was opened, issued by the King in Normandy and appointing Geoffrey, Bishop of Coutances, commissioner to preside in meo loco. 2. The King's writ of execution, of uncertain date, but probably not long after the suit, addressed to the Sheriff of Worcester and others, directing that the judgment of the court be carried into effect. 3. A formal report addressed by Geoffrey of Coutances to the Domesday commissioners for Worcestershire, concerned chiefly with the judgment rendered by the court, and presumably to be dated 1086 . 4. The record of a compromise by which was settled a case which had arisen before the Domesday commissioners involving practically the same questions and the same lands. The settlement would be of the date 1086 and the record is very likely of the same date. 5. An historical account of the original suit, calling itself Commemoratio placiti, written after the death of William I. ${ }^{4}$ but during the lifetime of many persons present at the trial, and occasioned it would seem by a threat of the Abbot's brother to bring the results of that case again into question. ${ }^{5}$ While this

before the Domesday record. See Feudal England, 294, 301-306, V. C. $H$. Worc., 256-257. Professor Liebermann has accepted Round's evidence for the feudalization of the Evesham lands: Dies krönt den Beweis, he says of it, with reference to Round's whole argument on knight service. Deutsche Zeitschrift für Geschichtswissenschaft, VII. E. 23. More recently he has expressed a doubt whether the Conqueror would compel a man like Wulfstan to degrade the ownership of his episcopal lands into feudal tenure. National Assembly, 78. Round's argument from the three knights fees held by the King of the bishop in 1166 seems to me unanswerable as to the fact of subinfeudation. It is impossible to suppose that the service could have been imposed on these lands after they passed into the lands of the King, and it is equally difficult to believe that subinfeudation would have been introduced if the bishop had not become the King's vassal. Maitland, Bracton's Note Book, No. 758, shows the ease with which an old Saxon service could be interpreted as feudal $C f$. Vinogradoff, English Society in the Eleventh Century, 67.

4 The writ under which the trial was held is breve et preceptum regis Willelmi senioris. Later it is said that there are many survivors who heard the trial, et adhuc multi de tempore regis Willelmi idem testificantes. Bigelow, Placita Anglo-Normannica, 17 and 18.

- The witnesses are "parati hoc probare per sacramentum et bellum contra Rannulfum fratrem ejusdem Walteri abbatis, quem ibi viderunt, qui cum fratre suo tenebal illud placitum contra episcopum, si hanc conventionem negare voluerit, factam inter episcopum et abbatem". Ibid. 19. See Round, Feud. Engl., 302, note. 
is the latest of the documents in date, it gives the fullest acount of the case, and it will be necessary to use it as if it were contemporary with the suit. ${ }^{\circ}$ These documents fit perfectly together, with the slight discrepancies to be noted below, and constitute a very satisfactory record for so early a date.

William's writ authorizing the trial is quite general in character. While it is made clear that the case is to be tried in a King's Court, ${ }^{7}$ the statement of the points in dispute is so vague that almost any question between the two parties might have been tried under it. Still more to the purpose is the fact that no directions whatever were given to Geoffrey as to how he should proceed and no description of the court to be formed. It would seem certain, therefore, that the King knew that Geoffrey would understand what to do and what should be the composition of the court under such a writ. The process was a familiar one to both of them.

B All these documents are printed by Bigelow, the Commemoratio and No. 2 in his text, pp. 17-19, from Thorpe, Diplomatarizm, 440-442, the others in Appendix A. No. 1 is No. 184 in Davis, Regesta Regum AngloNormannortsm, hereafter cited as Davis, Calendar; No. 2 is Davis, No. 230 ; and No. 3 is Davis, No. 221.

7 The in meo loco of the writ implies that the court is one over which the King might naturally preside. It is a court of his. Stubbs, Constitutional History, I. 419 (1897). The appointment of commissioners by royal writ in judicial cases is a delegation to them of position and authority belonging to the King. The court so constituted is not limited in membership to the ordinary membership of the local court whose testimony is desired, but may be made to approach more or less nearly to that of a great curia regis. It seemed natural to the writer of the Acts of Lanfranc to call the Penenden Heath court a magnum placitum, which is a frequent name during the first century for the national assembly. Plummer, Two Saxon Chronicles, I. 289; Thorpe, Anglo-Saxon Chronicle (Rolls Series), I. 387. $C f$. Stubbs, I. 301. The same is true of the conventus magnus of the Commemoratio above.. The court in which the sheriff tried a case per breve regis was not called, so far as $\mathrm{I} k \mathrm{know}$, curia regis. ( $C f$. Liebermann, Gesetze der Angelsachsen, II. 451, 10 c.) It was the ordinary county court and tried the case by county law (Glanvill, IX. 10, XII. 23), but the function of the sheriff in such cases was clearly distinguished from his ordinary function. $\mathrm{He}$ is mentioned always in Glanvill as acting per breve regis, and see especially Bracton f. $154 \mathrm{~b}$ (ed. Twiss, II. 542) : "Protest quidem vicecomes tenere plura placita quae non sunt ex officio vicecomitis sed vice ipsius regis et ex cansa necessaria, non sicut vicecomes sed sicut justitiarius regis ***'. It is convenient to distinguish this court from the ordinary sheriff's county court by calling it a King's county court. 
If we ask our earliest documents what was the composition of the court which tried the case, there seems no doubt about the answer. The King says in No. 2 that the case was tried before certain barons, testante vicecomitatu (sheriffdom, county). Geoffrey says in No. 3 that it was tried before certain barons of the King, judicante et testificante omni vicecomitatu. That is, the county was present in some capacity and took some part in the action, and barons, it would seem from their especial mention not usually forming any part of the county court, were present-a combination strikingly like the later itinerant justice court. The Commemoratio, however, differs from these earlier statements in two particulars. It says that the court was a conventus magnus $* * * * *$ vicinorum comitatuum et baronum, and it makes no mention of any action by the county, saying that the medial judgment, of which it gives a full account and by which the proof was awarded to the bishop, was made by the barons. ${ }^{8}$ I do not think that the variations of this later account are of importance. When we notice the emphasis which the Commemoratio places on the baronial element in the court, making no mention of any other, and consider that it would be perfectly regular for the justiciar to summon barons from any county to a King's court of this kind, we are hardly justified in allowing enough weight on these points to the later account to compel us to modify the definite statements of the two earlier documents. It would seem probable that the comventus vicinorum comitatuum if accurate at all, refers exclusively to the baronial element and that the county proper which was present was Worcestershire alons. It is probable also that the two earlier documents, though less detailed, should outweight the later on the point of action by the county, though even if we could say that the county court was the formally acting body in making the judgment, the Commemoratio is no doubt right in emphasizing the great influence which the baronial element in the body would naturally exert.

The Commemoratio is the only document which gives any detailed information on the procedure made use of in the case, and as it appeals to the testimony of many living persons and proposes a similar procedure in the prospective suit, we may accept its statements with confidence. The procedure is that with which

s "Tandem ex precepto justitiae regis et decreto baronum, itum est ad juditium et, quia abbas dixit se testes contra episcopum non habcre, judicatum est ab optimatibus quod episcopus ***”. Bigelow, 18. 
we are familiar as common in such cases. Each of the two parties presents his side of the case; the bishop produces his witnesses who had seen in the time of Kind Edward the services performed which he demands; the abbot is able to bring forward no witnesses. The Court then proceeds to award the proof, in this case to the plaintiff, ${ }^{9}$ it is expressly stated, because the defendant has no witnesses, allowing the defendant, however, to choose the relics on which the oath shall be taken. ${ }^{10}$ The case is then adjourned to a later session of the Court to which Geoffrey summons the barons who were present in the first session. ${ }^{11}$

${ }^{9}$ See the last note; Adams, Origin of the English Constitution, 118, note; Holdsworth, History of English Law, II. 135; Essays in AngloSaxon Law, 186, 240.

${ }^{10}$ A privilege to the defendant which would enable him to give to the oath something of the character of an ordeal, and which may have been granted because the proof is here awarded to the plaintiff. Such decisions show some option still left the court in spite of the formalism of procedure. In a Lincolnshire roll of 1202 are three cases in which the appellee is allowed to decide who shall make proof and in all he decides that the appellor shall. In all the appellor withdraws. Maitland, Select Pleas of the Crown (Selden Society), 10 and n. 3. See a similar case in Normandy in 1213, Delisle, Jugements de lExchiquier, No. 113, and $c f$. the award and the result in a case before William in Normandy in 1060-1066, Round, Calendar of Documents Preserved in France, No. 1172. An offered oath is refused also in Ibid. No. 78 (A. D. 1080). In this Worcestershire case, Geoffrey's report (No. 3) seems to imply that the oath was made: hoc fuit diratiocinatum et juratum.coram me, but he may be referring to testimony of the county, given in some way in the case but not recorded, or to the general result of the trial.

11 "* * * ex ex precepto Gosfridi episcopi, affuerunt barones qui interIfuerant priori placito et juditio" (Bigelow, 18), which makes it evident that they were not regular members of the county court. The conventus magnus *** vicinorum comitatum et baronum shows the same fact which is also more or less clearly implied in other cases here discussed. See notes 20 and 44 . When the justiciar was acting as the King's deputy or lieutenant (Stubbs, I. 299, 374) in the absence of the King, there can i,e no question of his right to issue writs. See Davis, Cal., No. 7 (Round: Fend. Engl. 430, n. 19). The justiciars in 1075 summoned the rebel earls to the curia regis, illi vero praeceptis corum obsecundare contemmun. Orderic Vitalis (ed. Le Prevost), II. 263. See Madox, Exchequer, I. 34, r. $u$; Gervase of Canterbury (Rolls Series), I. 376 (Eyton, Itinerary of Henry $I I ., 279-280$ ), and below n. 24. That a mere commissioner could himself issue a writ while the King was in the country is not probable. This consideration may increase somewhat the likelihood that Geoffrey acted as justiciar with Lanfranc and the Count of Mortain (Stubbs, I. 375) about the year 1082 and give to this case approximately that date. 
In the second session the abbot attends with his relics, but seeing the readiness of the bishop to take the oath, and the whole proof ready to be made, he abandons the case which is then closed by a concord and conventio. As to the method of proof used in the trial and offered in case of a second trial, there can be no doubt but that it was proof by witnesses and not compurgation. The emphasis placed on seeing and hearing alone would indicate that. ${ }^{12}$ In the second case, however, it is the Norman method of that. ${ }^{12}$ In the second case, however, it is the Norman method of witness proof which is proposed as is evident from the offer of battle, ${ }^{3}$

The original writ (No. 1) is addressed to the same persons as two of the Ely documents below (Davis, Cal., Nos. 156, 151) Lanfranc and Geoltrey, though the commission to act as justice here is to Geoffrey alone.

12 Essays in Anglo-Sax. Law, 186-188; Liebermann, Gesetze der Angeisachsen, I. 398, c. 8 ; Leis Willelme, c. 24 ; in a case before the King in Normandy, 1072-1079, "affuerant etiam antiqutssmi hommes qui hec viaerant et andierant parati probare secundum judicum regis quod nos edisseramus. Memoires de Antiquaires de Normandie, XV. 196, Round, Cal., No. 1190. Cf. Brunner, Entstehung der Schurgerichte, 54. I have not attempted to draw evidence as to procedure from any continental source except Norman, though it might be done. The Norman evidence is, it seems to me, conclusive of the fact that in the matter of the procedure used in the local courts the parallel between Saxon and Norman was so close that it is almost a matter of indifference whether we say that the Saxon survived or that the Norman took its place. In most particulars no conscious choice between them could have been made by contemporaries.

13 On battle as a feature of the Norman witness proof see Brunner, 1. c., 68, 198-199; Thayer, Development of Trial by Jury, 17, 40. The capitulary referred to by both and quoted in full in Thayer is now to be found in a later edition by Boretius, in the Monumenta, Capitula Regum Francormm, I. 282 . That churches and clerics should offer battle was not unusual. See Liebermann, Gesetze, II. Rechtsglossar, art., Zweikampf, 7e and $\mathrm{g}$. William interfered in such a case in Normandy (1074) ne causa Ecclesie determinaretur humano sanguine. Round, Cal., No. 165; Davis, Cal., No. 73. Text from Valin, Le Duc de Normandie et Sa Cour, 198, note. See William's law regarding procedure, Liebermann, Gesetze, I. 483-484, protecting the Englishman against compulsory trial by battle in criminal cases. A case which has been often referred to is recorded in Domesday Book, I. 44b (Bigelow, Placita, 38) which seems to include an issue drawn between an older and a newer method, or principle, of proof by witnesses. It would appear from the context that Picot asserts that his testes, men of low rank, are of equal value or better than those of higher standing produced by William, and that the court, puzzled perhaps by the emphasis of his assertion, refers the question to the King. "Sed testes Willelmi nolunt accipere legem nisi regis Edwardi usque dum diffiniatur per regem", which implies an admission that the principle of the older 
and presumably this was also the case in the actual trial. ${ }^{14}$

The case which comes before the Domesday commissioners in 1086 indicates that, though the first case had been decided in the Bishop's favor, he had not been able to obtain from Hampton and Bengeworth the services and payments for which he had sued. He lays claim now therefore not to servitia et consuetudines but to these lands themselves, to be held by him in clomain, a claim which can' only mean continued default of service. The commissioners apparently sent to Geoffrey to find out exactly what had been decided in the first case and received in reply Document No. 3, which all our evidence indicates to be a very exact statement. With this before them and with the confession of the abbot to the facts established in the first case, and very likely with the testimony of the county, ${ }^{15}$ it seemed to them and to the others that the lands should remain in the possession of Evesham, but that the abbot should be obligated to a faithful performance of the services, and to this the abbot consented.

Of the more famous case of Lanfranc against Odo, Bishop of Bayeux, commonly known as the Penenden Heath case, we have less satisfactory accounts. ${ }^{16}$ Happily these accounts, while differ-

practice, on which the testes of William stand, might be overruled by the king. Cf. Leges Henrici, 29, 1.; Thayer, Dev. of Jury, 23-24. Freeman, Norm. Conq., V. App. A, I think misunderstood this passage. The question primarily in dispute is one of fact, not of law. It is, who was the antecessor. That being settled, the disposition of the land is settled, as in i hundred other cases in the record. What is peculiar and new, is the character of the proof offered by Picot. The sentence quoted above can hardly bear any wider meaning than that the testes of William refuse to yield to a method of proof (legem) which they think is not warranted by precedent, until the point is decided by the King.

14. Bigelow says, citing this case, "This form of testimony by witnesses, unrestrained by the limits apparently set in the Anglo-Saxon period, was employed in the time of the Conqueror". Placita, xxi and n. 3. See Brunner, Schwurgerichte, 399-400. There is an interesting case in Normandy of the employment of charter witnesses about 1040, in which William is mentioned as acting, in Delisle, Saint Sauveur-le-Vicomte, pièces, No. 14, p. 17.

15 Not so stated in the record but in Heming's account of this case in his cartulary, written by direction of Bishop Wulfstan. Quoted in Bigelow, Placita, 288 . It is practically certain that only one county gave testimony in the case in 1086 .

16 See Freeman, Norm. Conq., IV. 244-247; Stubbs, I. 300-301. Stubl:s says this is "perhaps the best reported trial of the reign", but he does not seem to have known of the evidence bearing on the Worcestershire case. See Ibid., I. 299, n. 3. 
ing in some particulars among themselves, agree in those which are essential for our purpose. According to the longer account Bishop Odo, ${ }^{17}$ coming to England some years before Lanfranc, was able to seize upon many lands and consuetudines belonging to the archbishopric. Soon after Lanfranc became primate, he made diligent inquiry into the matter and, discovering the losses of his church, appealed to the King for redress. Thereupon the King in 1072 issued his writ to Geoffrey of Coutances directing the county to sit upon the case under him as justice. ${ }^{18}$ The

17 Printed in Bigelow, Placita, 5-9, from the notes to John Selden's edition of Eadmer (1623), 197-200. For an incomplete but dated copy of the shorter text, together with a discussion of earlier printed copies and of the date, see Dr. W. Levison in the English Historical Review, XXVII, 717-720 (1912). The account printed by Dr. Levison, which lacks the historical introduction and some details of the longer account, has more the appearance of a formal record, or the original record but slightly changed. If it be taken as such, the longer account as printed by Bigelow from Selden will show how the later historian with the record before him added cietails to complete the narrative, and may possibly indicate what was done in other narratives based on a record, as in the Commenmoratio in the Worcestershire case above, the first Ely case, and the case of Bishop Gundillf v. Picot below. Nothing was added by the historian in the Penenden case which affects the points we are considering here, and probably nothing was in the other cases, though the Ely case is badly confused. The writ printed by Bigelow, p. 4 (Davis, Cal., No. 50), upon which he says the trial appears to have been instituted, can hardly have a connection with the case. At a time, when the forms of writs were still unsettled, this writ might perhaps have been interpreted, in a second stage of the action it contemplates, as an original judicial writ; it seems rather to be an executive writ. It names among the commissioners Lanfranc, who is plaintiff in the Penenden case, and it concerns domain lands only. Without a good deal of laxity in judicial interpretation, no church could have recovered under it any land which it held in servitio.

18 The county met ex precepto regis. E. H. R., XXVII, 719. "Huic flacito interfuerunt Goisfridus episcopus Constanticnsis qui in loco regis fuit et justitian illam temit ***" Bigelow, 7. It would be apparent that this was a curia regis held in the county, if from no other evidence, because in it "multa*** verba***ibi surrexernnt et etian inter consuetudines regales et archiepiscopales" (Both texts). This was business in which the King had a direct interest. The same thing is implied by the Rechtsgebot of which the closing sentence in Bigelow is a good example: "Hujus placiti * * determinatum finem postquam rex andivit, laudavit, landans cum conscnsu omnium. principum suarum confirmavit, et ut deinccps incorruptus preserverarct, firmiter praecepit." These words may possibly imply action by ti e central curia regis, but whether such action was taken or not, the King's here described would give the decision of the local court the same effect. 
county came together at Penenden and, because of the number of questions needing to be settled, was held in session for three days. ${ }^{19}$ Besides the ordinary County Court there were present barons - Francigenas-of the county, who probably would not usually attend, and barons from other counties. ${ }^{20}$ The Bishop of Chichester is named as having been specially summoned by royal writ, ex praecepto regis, to give information about the ancient consuetudines. $^{21}$ In this case we have then, as in the first, a County Court reinforced by barons not usually belonging to it, summoned before a royal commissioner who was acting as presiding justice in place of the King, qui in loco regis fuit et justitiam illam tenuit, a King's County Court.

As to the procedure employed, we are given almost no information. That the county had something to do which was considered essential seems to follow from the fact that it was detained for three days, but we get no details of its action. The statement as to the judgment reached implies that barons and county acted together in making it: "Et ab omnibus illis probis et sapientibus hominibus qui affuerunt fuit ita ibi diratiocinatum et etiam a toto

${ }^{19} \mathrm{Cf}$. Magna Carta, c. 19. This implies the presence of the County Court.

20 "*** et alii multi barones regis et ipsius achiepiscopi atque illorum episcoporum honines multi, et alii aliorum comitatuum homines etiam cum toto isto comitatu multae et magnae auctoritatis viri, Francigenae scilicet et Angli." Bigelow, 8. There is no evidence of any county court officially present except that of Kent.

21 Consuetudines here are of the same sort as in the preceding case. Strictly speaking, the bishop was not brought to testify as to the laws of the land or the ancient customs of England (Freeman, Norm. Conq., IV. 425 ) in the meaning usually given to these terms. In proving, however, to whom the Saxon consuetudines belonged in order to prove to whom they should belong after the Conquest, it is necessarily implied that the rights remain the same, as is also implied in regard to the royal consuetudines later in the account of this case. There would be therefore in such cases more truly a carrying over of Saxon legal arrangements than in the mere transfer of land from the old to the new holder, which need imply nothing as to the form or nature of the holding. This is also true of the continuation of sac and soc, liberties, and immunities. There is an interesting case under Henry II. of disputed jurisdiction turning on the question of fact, to whom the Saxon grant had been made, in the Chronicle of Joselin de Brakelonda (Camden Society), p. 37. All of these things differed, however, in principle in nothing from similar Norman arrangements, and probably very little in detail. See Haskins, American Hisiorical Review, XIV., 458ff, and below n. 34 . 
comitatu recordatum et judicatum." 22 In regard to the method of trial it is implied only that both witnesses and argument, or discussion, were employed. The end was determined multis testibus multisque rationibus, and in the presence of all multis et apertissimis rationibus demonstratum fuit. . While these statements are unsatisfactory and warrant no more detailed inferences than those made above, they are so far as they go entirely in harmony with the Worcestershire case, and with what we should expect.

The case of the Church of Ely presents some peculiar difficulties from the incompleteness of the sources. It is probably impossible with any certainty to arrange chronologically the documents concerning the rights and lands of Ely which belong to the reign of William $I^{23}$ If we place them with reference to the facts which they concern in the order from internal evidence seems more likely than any other, we have first a document (122) included in the Liber Eliensis having some of the forms of a record, but mainly a historical narrative, manifestly written some time after the event and so indefinite and uncertain in character as to be of little value. Two facts only it seems to establish satisfactorily. 1. A case concerning the "liberties" of Ely was tried before a royal commission. Whether the commission was issued to Odo of Bayeux as the presiding justice, or Odo as justiciar himself commissioned the justices upon the King's order, is not apparent. ${ }^{24}$ Either proceeding would in general be possible. The

22 The new version of the shorter account printed by Dr. Levison (E. H. R., XXVII., 719) varies these words slightly: "Et ab ommibus sapientibus, qui affuerant, fuit ibi diracionatum atque judicatum $a * * *$ ". Presumably the word comitatu should follow. The brief accounts in Eadmer (Rolls Series, p. 17) and Gervase of Canterbury (Rolls Series, II., 369) add nothing to the records used here and are so late in date that they can stand only for the traditional understanding. Eadmer, who relates briefly the same historical circumstances as the longer account, calls the meeting a conventus principum, but mentions the county and says of the decision that it was ex communi omnium astipulatione et judicio. Gervase knows nothing of the county and speaks of the suit as "in congregatione illa famosa nobilium Angliae et seniorum quae ex praecepto regis facta est apud Pinindene".

${ }^{23}$ These documents are printed in Bigelow, Placita, 22-29 from the Liber Eliensis, except the last one considered. The numbers in parenthesis in the text are the numbers assigned to the different documents in Davis's Calendar. See Freeman, Norm. Conq., IV. 327 ; Round, Feud. Engl., 459, 461.

${ }^{24}$ It has been generally supposed that the presiding justice in this case was the Bishop of Bayeux, but the language is what would have been used 
latter seems from the language more probable in this case. 2 . It seemed to the person writing that the Court could properly be formed by several counties, or the representatives of several counties, united. What the counties were or how may, or in what way they were united, it is not possible to say. ${ }^{25}$ The account at first says three counties were united, but later the number is given as four, and altogether the representatives of at least seven are named. The description is so vague and confused that we can only say that a combination of counties, or representatives of counties, to form a single Court seemed possible to the author. The second document (129) appears at first sight to be a writ of execution following this case. It names the same place of trial, and the same subject, the liberties of Ely, established per pluras scyres ante meos barones, but it names so different a commission before whom the case had been tried, headed by Geoffrey of Coutances, not likely to be forgotten, that the relationship of the two documents must be left in doubt. ${ }^{26}$ All we can say is that

if the King, absent from England, had issued his writs through Bishop Odo as justiciar: "rex tandem respectu divinae misericardiae instinctus his intendere, principibus circumpositis per Baiocensem episcopum praecepit haec discutere." The historical record (122) is dated April 2, 1080. William was in Normandy at that time (Davis, Cal. p. xxii), but we do not know that Odo was justiciar then. See notes 11 and 38, and Stubbs, I. 375. It seems to be implied in No. 129 that Geoffrey of Coutances was the presiding justice.

${ }^{25}$ In Davis, Calendar, No. 122, this is said to be a "record of an inquest $* * *$ by the oath of the three neighboring shires". The statement is an inference, perhaps probable, but the fact is not directly affirmed in the document. $C \dot{f}$. Ibid. p. xxix. Nor is anything more definite said in No. 129. That several counties were united on occasions like this in some capacity admits of no question. See evidence in the cases here following and $V . C . H$. Worc., 254. For evidence of a similar union of several counties in one court in the Frankish state see Waitz, Deutsche Verfassungsgeschichte, IV. 411-413. Cf. Round, Cal., No. 737.

26 When a document like this writ is opposed to a historical account plainly inexact, the normal conclusion would be that the writ is correct, and perhaps there is less difficulty in supposing Geoffrey's presence to have been forgotten than that two trials were held with so many features in common. This would imply, however, that Odo took no other part in the case and that he was acting as justiciar, or at least that he issued the convoking writs in the King's name. See above n. 24 . It is to be noted also that the barons named in the writ as those before whom the case was tried are ten in number, a considerably larger body than the usual commission, and that the writ of Henry I. (Monasticon, I. 482), which follows his father's in part, names a commission of five, four named in William's writ, and one, Walkelin, Bishop of Winchester, an entirely new name. 
this relates also to a King's Local Court of more than one shire presided over by a royal commission.

An especially interesting commission is No. 155. It concerns not the liberties but the lands of Ely, once held in domain but now usurped by barons. ${ }^{23}$ Referring to an earlier suit on the same subject, it directs all the shires which were present in the former case to be reconvened, and those who can come 'of the barons who were present before, and those who hold lands of the church. ${ }^{28}$ When they are assembled, there are to be selected several of those English who know how the lands of the church were lying on the day on which King Edward died, and what they report is to be attested by oath. ${ }^{29}$ Plainly this is the Norman jury of inquisition, and the directions are especially interesting as an early and clear statement of both the process and the principle of the jury and of its use in a suit at law. It is evidently expected that two classes of land will be found, one about which there will be no doubt but that they belong to the domain. These lands are to be restored at once unless the holders can make terms with the abbot. The other class is of lands whose holders set up the plea that they received them from the King. ${ }^{30}$ Of these the King directs that it shall be signified to him in writing what the lands are and who hold them. It would seem that this document was followed after

27 It is therefore, if the language is used strictly, as it is likely to be, not the above case.

28 "Mando vobis et praecipio ut iterum faciatis congregari omnes scyras quae interfuerunt placito habito de terris ecclesiae de Heli, antequam mea conjux in Normanmiam novissime veniret. Cum quibus etiam sint de baronibus meis qui competenter adesse poterunt, et praedicto placito interfucrunt, et qui terras ejusdem ecclesiae tenent." Bigelow, 24. Those who hold lands of the church are parties interested in the case before the court and are hardly summoned as among the "baronibus meis" who, according to the language usual in these documents, form a part of the court. This is not, I think, a second session of the earlier placitum referred to, for which the writ would surely read differently, but a new trial.

${ }^{29}$ Following immediately on the passage quoted in the last note, it is said: Quibus in unum congregatis, eligantur. plures de illis Anglis qui sciunt quomodo terrae jacebant praefatae ecclesiac die qua rex Edwardus obiit, et quod inde dixerint ibidem jurando testentur". This is the same as the arrangement referred to in the record cited in note below from the Inquisitio Eliensis: "testimonio hominum rei veritatem cognoscentium". The two placita concerned the same subject and employed the same method.

${ }^{30}$ The term "thaneland" is applied in this writ to both these classes of land, to that held of the church as well as to that held of the King. 
no long interval by No. 276. In the latter not all the. land of either of the classes of the former document has been restored to the church. The domain of the abbot is here distinguished from the domain of the monks, which looks like more careful considerand is not yet in possession of all his consuetudines, which need not mean, however, a failure to carry out the decision of the Court referred to in No. 129. Lanfranc is not named among the commissioners as in most of the other cases, and no directions are given as to the formation of a Court, but the assembly is called istud placitum.

Of the other Ely documents of this immediate group, only No. 154 concerns us. ${ }^{32}$ It appoints a commission for the trial of a possible suit concerning consuetudines claimed by Bishop Remigius in the island of Ely which are suspected to be new. The King declares that he is unwilling that the bishop should have any rights there except those which his predecessor had on the day of King Edward's death, and if the bishop wishes to go to law about the matter, directs that he shall plead as he would have done in King Edward's time. ${ }^{33}$ At first sight these words seem to mean that the bishop must employ the same procedure that he would have done in Edward's time, but if so this is the only time in cases of this kind that William shows any interest in pro-

ation. ${ }^{31}$ Abbot Symeon has probably recently come into office

31"Facite simul venire omnes illos qui terras tenent de dominico victu cclesiae de Heli ***”. See Ramsey Cartulary (Rolls Series), I. 234.

32 Nos. 151, 152, and 153, seem almost beyond question to have been issued in that order, as may be seen from the references to the consecration of the abbot, and No. 154 may be placed next because of the reference to Remgiius. No. 151 is later, I think, than 155 and 276 , because of the reference to the abbot's lands and the sicut alia vice praecepi. Nos. 156 and 157 are later than 155, but their exact position in the series can hardly be determined. It is quite likely that some of these documents were practically contemporary, that is, certain of them were issued before others had been executed. Several of them vaguely imply that the King was out of the country.

${ }_{33}$ "Nolo enim ut ibi habeat nisi illud quod antecessor ejus habebat tempore regis Eadwardi, scilicet qua die ipse rex mortuus est, et si Remigius cpiscopus inde placitare volucrit, placitet inde sicut fecisset tempore regis Eadwardi ***". Later in the same writ it is directed that a suit begun by certain barons against the church is to be postponed "si inde placitare nolucrint sicut inde placitassent tempore regis Eadwardi". Further on a little indication of procedure is given, in line with what we have had. The abbey is to have its consuetudines "sicut abbas per cartes suas ct per testes suos eas deplacitare poterit". 
cedure, or any consciousness that procedure had changed. What William is everywhere anxious to have established is the fact about the Saxon antecessor. What was the land which he held? What were the contents of the liberty? What were the rights and consuetudines? Nothing further than this. ${ }^{34}$ Again if we regard the question from the side of procedure, the Saxon and the Norman methods of proof were so nearly identical that it would be impossible to point out any peculiarity of the Saxon, differing from the Norman, which would be a protection to a defendant and which he might wish to have preserved. What is wanted in this case is to find out what rights were exercised by the bishop of Edward's time, and what is demanded is that Remigius should prove his case by evidence which existed in 1066 and by nothing which he could not have used in that year. He must be limited in his pleadings to the facts as they existed in Edward's day.

There is another document relating to the lands of Ely not included in the above list which records the results of a placitum held before a royal commission of five, Bishops Geoffrey and Remigius, Earl Waltheof, and Sheriffs Picot and Ilbert. ${ }^{35}$ The

34 The question of the manner of holding, the kind of tenure, is not raised. The fact of Saxon ownership is unquestionably used to prove title after the conquest, but nothing more. ( $C f$. Pollock and Maitland, History of English Law, I. 92 ; Vinogradoff, English Society, 224). There is nothing in such inquiries as this, or in inquiries as to liberties and consuctudines, as in the Worcestershire case, which implies the impossibility of so much of a revolution in land tenures as would be made necessary by the general introduction of military tenure where it had not existed before. I am not taking into account here intra-manorial tenures proper, and also important incidents of land holding are indicated by sac and soc and consuetudines, but practically the same things are so closely bound up with land holding in Normandy that their existence in England would assist rather than hinder the introduction of the complete Norman system. The general subject of the survival of Saxon law after the Conquest I am also not discussing in this paper. There is much evidence upon it, but minute and exact study of details is greatly needed.

3. Hamilton, Inquisitio Comitatus Cantabrigiensis, 192; Round, Feud. Engl., 459-461. One is tempted to try to fit this document into the series first named and to guess that it relates to the placitum mentioned in No. 155 as held antequam mea conjux in Normanniam novissime veniret, that the list of lands (Hamilton, Inq. Cantabr., 192-195) was then made out; and that it is the one concerning which the king asks. for information in No. 152: "Inquire per episcopum Constantiensem et per episcopum Walchelinum, et per caeteros, qui terras sanctae AEtheldrithae scribi et jurare 
King's writ besides appointing the justices directed the assembiing of the county before them. In the Court an inquest was held and "testimonio hominum rei veritatem cognoscentium determinaverunt terras que injuste fuerant ablate ab ecclesis * * * * * quatinus de dominio fuerant, tempore videlicet regis Edwardi." There follows a list of those who had usurped lands of the church with the holdings which they unjustly possessed. The jury of those who know is evident, but no further indication of procedure is given and no evidence that the Court included a special baronial element besides the royal justices.

A case interesting in many ways is that between Bishop Gundulf of Rochester and Picot, Sheriff of Cambridgeshire, over land of Francenham, which Picot claimed was the King's. ${ }^{36}$ The County Court met to decide the right by their judgment, as directed by the King, under the Bishop of Bayeux as King's commissioner. Influenced by fear of the sheriff, they decided against Gundulf. So far as the record goes, it is the County Court which makes the judgment, and no baronial element is mentioned besides the King's justice. By what procedure the case was tried is not indicated. The Bishop of Bayeux, however, suspected the decision and was unwilling to accept it. ${ }^{37}$ He directed the court

fecerunt, quomodo juratae fuerunt, et qui eas juraverunt, et qui jurationem audierunt, et quae sunt terrae, et quantae, et quot, et quomodo vocatae, et qui eas tenent." At the date of 152 the King has learned of this list and he wants to know how it was made and practically demands a copy of it. The report called for in 152 is considerably more detailed than that asked for in 155 . Then he asked for information about the lands said to be held of him: "Illas vero litteris mihi signate, quae sint et qui eas tenent." If Matilda was in England during the absence, or absences, of William, 1075-1080 (see Davis, Cal., No. 189, Bigelow, Placita, 33), the reference to her in No. 155 would make probable the order here suggested for the first two of these documents, and William's absence would account for his not knowing the results of the placitum. Round, Feud. Engl., 133ff, thinks the whole Inquisitio Eliensis was drawn up in answer to No. 152 and that the writ refers to the Domesday survey. Davis's date of 1082 is more likely.

${ }^{36}$ Bigelow, Placita, 34, from Anglia Sacra, I. 339 ; Madox Exchequer, I. 31 ; Freeman, Norn. Cong., IV. 249 ; Round, Feud. Engl., 121 ; Holds. worth, Hist. Engl. Law, II. 135.

37 There is a commission of Henry I's to a sheriff and three others to view boundaries "*** et facite recognoscere per probos homines de comitatu. ***Et si bene eis non credideritis, sacramento confirment quod dixerint". Palgrave, Commonzealth, II. 184 n. 84 from Monasticon VI. 1273 (Vol. VIII. ed. 1846). 
if they knew they had. spoken the truth, that is, if they wished to maintain their judgment, to choose twelve of their numberseipsis duodecim eligerent-who should confirm by an oath what all had said. This they did and here the case rested for a time. It should be noticed that the presiding justice assumes to direct the court to take action supplementary to a decision usually final and such as never would have been taken at that date by an ordinary County Court. ${ }^{38}$

Of no other case in the reign of the first Norman King, do we have particulary significant details. If we count, as I think we must, four separate cases in the interest of Ely, with a possible fifth, we have considered above seven cases, and perhaps found an eighth. There are mentioned during the reign eight other cases and a probable ninth. ${ }^{38}$ Of these three are referred to in

38 The later portion of the case does not concern our present purpose, as it is carried on not in a local but a general curia regis. It is interesting to notice, however, that the court (multos ex melioribus totius Angliae baronibus) is summoned to London not by the King but by the Bishop of Bayeux; that the jury of the county is put on trial before this court on an accusation of perjury and convicted; and not merely this, but that the judgment of the first court is set aside, contrary to the usual practice, and the land assigned by that judgment to the King is given back to Bishop Gundulf. The whole case is extraordinary in the matter of procedure and is a striking example of how far the new rulers might allow themselves to go in interfering with the older judicial customs, very likely in the interests of justice.

39 There are fewer instances of similar commissions in Normandy cluring the same reign. A probable case is found in a document of about 1036: "Quo vero clamore prolato in medio, invenerent, Robertus sc. archiepiscopus, Odo comes, et Niellus vicccomes aliique seniores justiciam regni obtinentes, quod illas terras ***". Delisle, S. Sauveur, p. 14, No. 13. Not long after 1070, two barons were commissioned to make an inquiry under oath which they were to record, and this was done. Gallia Christiana, XI. instr. 65; Brunner, Schwurgerichte, 148, n. 4; Valin, Cour, $201, \mathrm{n} .1$. In 1076 there is an interesting case, probably not of missi, but of the delegation of the judicial authority of the curia regis to Geoffrey of Coutances ("Gaufredus, Constantiarum presul, est delegatus regali auctoritate discussor et judex hujus disceptationis") with others who seem to decide the case independently of the rest of the curia. Delisle, S. Sauveur, p. 40, No. 36; Round, Cal., No. 712; Davis, Cal., No. 92 . About 1080 there is another case very much like the last in which the authority of the curia regis is again delegated to Geoffrey with three others. Delisle, S. Sauveur, p. 46, No. 42; Round, Cal., No. 1212; Davis, Cal., No. 132. See Haskins, $A$. H. R., XIV. 472-475. On the pleas of the King of France held throughout the Vexin in 1091 see Round, Cal., No. 3. The 
Domesday Book, three in royal writs, two in the Miracles of St. Edmund, and one probable case in the Abington Chronicle. In one Domesday reference (I. 175 b.) it is said that Abbot Walter of Evesham recovered five hides in iiii sciris coram episcopo Baiocensi et aliis baronibus regis. In another (I. 2.) the case is said to have been decided judicio baronum regis qui placitum tenuernt. In the third case (I. 101b.) Bishop Osbern is said to have proved his title to a manor coram baronibus regis. In the first writ case (Davis, Cal. No. 66.) King William gives notice that Abbot Scotland had recovered eight prebends in Newington by the testimony of the County of Kent before Lanfranc and three other barons who are named and ceteris meis optimatibus illius comitatus. The second (Davis, No. 188) is an order by the King's son William to the Sheriff of Kent, directing him to make an inquisition regarding rights claimed by the Abbot of St. Augustine's, Canterbury. This is, I think, the only instance of the reign of the writs so frequent later by which the sheriff acting alone is made a royal commissioner for inquests and trials. In the third case (Davis, No. 213), Bishop Wulfstan, the Abbot of Evesham, and Rambald the chancellor, adjudged lands in Worcestershire to be held in domain by the Abbot of Westminster. Of the two St. Edmund's cases, one refers to what looks like an iter, ${ }^{40}$ and the other to a commission to Lanfranc to take the tes-

40 "*** presentibus ejusdem loci majoris actatis fratribus, sed et accitis illuc ab abbate quibusdam regis primoribus, qui dictante justitia in eadent villa regia tencbant placita." See Round, Fend. Engl., 329, and Davis, Cal., xxxi.

timony of the county in the case between St. Edmund's and Bishop Herfast. ${ }^{41}$ This last case was decided by the witness of

fact should not be overlooked that the character and operation of the court seem entirely familiar to all who are called upon to operate it. It is natural, as a result of the disturbance of titles made by the Conquest, that there should be more cases calling for the use of missi in the kingdom than in the duchy.

${ }^{41}$ For the first St. Edmund's case see Memorials of St. Edmund's Abbey (Rolls Series), 63, and Liebermann, Anglo-Normannische Geschichtsquellen, 253, and for the second, Memorials, 65, and Liebermann, 254, and $C f$. Davis, Cal., Nos. 138, 139, and Liebermann, in Zcitschrift $f$. Geschichtswissenschaft, VII. E. 34. For the Abingdon case see Chronicon Monasterii de Abingdon (Rolls Series), 1-2, (Davis, Cal., No. 49). I have omitted from this list the second case between Odo of Bayeux and Lanfranc because, while it may very likely be another instance of a local royal court, the account is so indefinite that no positive assertion is possible. 
the Abbot of Ramsey, reaching back to the days of Cnut and supported by the testimony of nine counties, or of the representatives of nine counties. In the Abingdon case no mention is made of royal commissioners, but the details given agree so exactly with the other cases of commissioners that it is probable one of the kind. Under the authorization of a royal writ, by a charter of King Edward's and the witness of the county, Abingdon proves its right to certain consuetudines against royal officials.

$I$ believe, if we leave one side the action of the counties before the Domesday commissioners, there is no other clear reference to judicial action by a County Court in the reign of the Conqueror. These which have been considered all agree among themselves in any details which they give, both as to the general plan in operation and the procedure in the conduct of the cases. Certain minor points only are left in doubt. The one feature in which all the cases agree without exception and with no room for doubt is the presence of the royal commissioners, the King's missi.

The Norman origin of the practice of sending a special justice, or justices, by a written order of the King's, to hold a local court for the trial of a specified case, is not likely to be questioned. No case of exactly the sort has bien found in Saxon times. ${ }^{42}$ If every case, however doubtful, of royal influence on popular courts in the Saxon period be allowed to be a forerunner of this practice, it springs into such sudden and extensive use in the reign of the

See Bigelow, Placita, 10, and Rule's edition of Eadmer (Rolls Series), 17-18. I have also omitted a case coram regina Mathilde in praesentia iiii vicecomitatumm (Domesday Book, 1. 238b; Bigelow, Placita, 300) for the Queen may be thought to represent the King in a more personal way than an ordinary commissioner, though the case is the same in principle. Matilda may indeed during the King's absence herself have issued the urits convoking the court. On the judicial action of the Domesday commissioners, see $V . C$. H., Suffolk, I. 385, and on other possible commissions, Ibid., 386, 379, and the references there.

42 Zinkeisen in the Political Science Quarterly, Vol. X (1895), 132ff, has studied the evidence for Saxon times with negative results. See Liebermann, Gcsctze, II. 482, 5a, 6a; Freemen, Norm. Conq., V. 298-299; Stubbs, I. 206. While no case clearly like that of the later missi with their specially constructed court is to be found in Saxon times, the King does occasionally send formal directions to the local courts in regard to cases before them. The evidence for this is cited from Kemble, Codex Diplomaticts, Nos. 693, 929, and more doubtful 755. These documents will be found in Essays in Anglo-Saxon Law, pp. 355, 360, and 365, respectively. 
Conqueror that we should be obliged to reckon it among the instances of the substitution of an institution in an advanced stage of development for one in its faint beginning. But the facts will hardly warrant us in claiming even so much as this for a Saxon forerunner, for there is no case in that period of royal commissioners holding a local court under a King's writ. We are certainly dealing here with a Norman institution, imported by the Conqueror, whose historical antecedents in Normandy and conrection with the Carolingian missi do not fall within our subject. $I$ believe that the frequency with which the process was put into use and the importance which it must have had as a means of government in the minds of the King and his advisers have never been realized. No comment made upon it and no list of cases drawn up have been at all adequate to indicate the place which it plainly occupied in the government of the time.43 If among the scanty records of the reign which have been preserved to us, we can discover fifteen undoubted cases in its twenty-one years, we may be sure that this method of bringing royal justice into the localities and of bringing local evidence and local knowledge to bear on royal justice was clearly understood, highly esteemed by those interested in government, and in practically constant employment, a most important new contribution to the institutional life of the state. There is, however, no sign that it was yet regularized or systematized except in the Domesday plan. The cases are unconnected, each arranged and carried through for itself alone. The evidence in one instance that commissioners on an iter may be in session relates to one place only and is too incomplete to warrant another conclusion. It is evident, however, that the method is so frequently employed and so well understood that it can easily be made regular and systematic by another generation.

In many of the cases, barons besides those forming the commission were summoned to attend the Court from the county in which the Court met, or from other countiss, or from both, and took part in the action of the Court. In a few cases they are not mentioned, but in these nothing precludes their presence. Their attendance would give to the Court more obviously to contemporaries the character of a King's Court and distinguish it

43 Stubbs, I. 375, 478; Pollock and Maitland, Hist. Engl. Law, I. 109, n. 2; Davis, England Under the Normans and Angevins, Appendix II., and Calendar, p. xxix. 
sharply from the ordinary County Court. ${ }^{44}$ Evidence that the judgment was made by them exclusively is not sufficient to warrant such a conclusion and appears to me of doubtful validity. In exactly what way the judgment was made in the later itinerant Justice Court, it is very difficult to say, but it is highly probable that both in them and in their ancestors in the time of William I. the baronial element in the Court exercised an influence upon the decision disproportionate to its numbers, but it seems to me more than likely that the decision was in form an act of the assembly as a whole.

In many of these cases the county is mentioned, or a group of counties, as attending the commissioners and taking some part in the action of the Court, and in places where there is no such referencs, its presence should probably be assumed. The county which attends is probably the County Court which meets the sheriff in its ordinary sessions. The language of the documents in most of the cases would be satisfied if we supposed attendance to be confined to a county jury which speaks for the county in giving testimony, as the hundred juries do for the hundred in Domesday Book. This may be the case in those instarices where several counties meet, except for the one county forming the Court, but the later itinerant justices certainly met a County Court, and it is difficult to see how such a practice could have developed out of one in which juries only attended. The natural development would be the other way. The case of Bishop Gundulf against Picot seems also to imply, though not necessarily, the jormation of a jury from an assembly on the spot. As to the action of the county in making the judgment, nothing further need be said except to call attention again to Geoffrey's judicante in document No. 3 in the Worcestershire case.

We have then in formation of the Court, first, the King's writ, the creative, constitutive fact, without which the Court would have no existence; second, the justice or justices, who represent the King, in meo loco, and who preside over and direct the action of the Court. These two points together determine not merely the

44 In the itinerant justice system of the twelfth and the first part of the thirteenth centuries, barons from the county, not attending the ordinary county court, were required to attend personally or by representatives, but, so far as I know, barons from other counties were not summoned in addition to the commissioners, though there was nothing in the ideas or practices of that time which would make a summons to them seem unwarranted. 
existence but the character of the Court. They make it a King's Court, differing from a great curia only in numbers and in the absence of the King. Its judgment is equivalent to a judgment of the great curia and is so accepted and proclaimed by the King. Third, there is present a specifically summoned baronial element, also a distinguishing mark of the Court and emphasizing its royal character, but apparently not a necessity; and fourth, as the local foundation of the Court, that which brings the local into contact with the royal, is the County Court, undoubtedly the old Saxon Shire Court. The purpose for which this Court is summoned is, however, not to constitute the Court. A local curia regis could unquestionably be constituted for the same purpose without its presence. It is needed to bring the local evidence and the local testimony to bear upon the case in the simplest and most natural way. The institution is essentially Norman in its constitution and in its place in government as a whole, that it, it belongs to the central, not to the local government. These cases should, therefore, not be cited as meetings of the original Saxon Shire Court, though they are evildence of its continued existence, but of this there is of course abundant other evidence.

As to procedure but little can be said, and that little of a general character. We have here no definite information of anything except witness proof and the jury or inquisition. The latter is Norman, the former in the case most fully given shows Norman characteristics. This is to be said of procedure, however, that all the methods of trial in use in Saxon England, compurgation, witness proof, charter proof, the ordeal, were familiar to the Normans in their own Courts in addition to battle and long-continued to be. ${ }^{45}$ Procedure in local Courts is distinctly one of those cases where Norman and English methods were so closely alike that they easily and imperceptibly ran together into one, and such slight innovations as the Normans may have made could hardly have seemed significant. Even battle which appears to have been unpopular was not out of harmony with Saxon methods. The king's local court and the jury were more decided innovations, but neither was revolutionary and both were adjusted easily to the older local organizations of justice.

Yale University.

George Burton Adams.

45 This statement hardly needs proof, but on the ordeal of the hot iron, see Davis, Cal., No. 146a, (Appendix, No. XVI), dated 5 September, 1082. For a case of its use in the time of William I., in what was probably the great curia of the duchy, see Orderic Vitalis, II. 433. 